OPEN ACCESS

Citation: Norberto Dallabrida(2021)Molding the plastic soul of youth: the Ratio Studiorum and the manifacture of educated and catholic subjects. Rivista di Storia dell'Educazione 8(1): 3-10. doi: 10.36253/rse-10424

Received: February 7, 2021

Accepted: March 13, 2021

Published: July 5, 2021

Copyright: (c) 2021 Norberto Dallabrida. This is an open access, peer-reviewed article published by Firenze University Press (http://www.fupress.com/rse) and distributed under the terms of the Creative Commons Attribution License, which permits unrestricted use, distribution, and reproduction in any medium, provided the original author and source are credited.

Data Availability Statement: All relevant data are within the paper and its Supporting Information files.

Competing Interests: The Author(s) declare(s) no conflict of interest.

Editor: Francesca Borruso, Università di Roma3.

\section{Molding the plastic soul of youth: the Ratio Studiorum and the manufacture of educated and catholic subjects}

\author{
Plasmare l'anima plastica dei giovani: la Ratio Studiorum e la \\ produzione di soggetti letterati e cattolici
}

\author{
Norberto DAllabrida \\ Università degli Studi di Santa Caterina \\ E-mail: norbertodallabrida@gmail.com
}

\begin{abstract}
This essay intends to re-read the Ratio Studiorum by analyzing its strategies and pedagogical tactics in the production of the subjectivity of Jesuitic students, in connection with the ascetic principles of the Society of Jesus and the social circumstances of a century characterized by religious reforms and wars.
\end{abstract}

Keywords: Ratio Studiorum, curriculum, Jesuit, subject.

Riassunto. Il saggio propone di rileggere la Ratio Studiorum, analizzandone le strategie e le tattiche pedagogiche nella produzione della soggettività degli studenti gesuiti, connesse con i principi ascetici della Compagnia di Gesù e con le circostanze sociali del secolo delle riforme e delle guerre di religione.

Parole chiave: Ratio Studiorum, curriculum, Gesuiti, soggetto.

The Ratio Studiorum was promulgated by the Society of Jesus in 1599, with the objective of serving as a pedagogic discourse standard of educational practices at Jesuit colleges. It molded important disciplinary pieces of the Jesuitic and Catholic "school machinery", which would be secularized and used by the school systems formulated by the Enlightenment and, mainly, by the bourgeois National State. A re-reading of the Ratio is intended as a "monument document", in the sense of analyzing its strategies and pedagogical tactics in the production of the subjectivity of Jesuit students, connected to the ascetic principles of the Society of Jesus, as well as to the social circumstances of a century of religious reforms and wars. The focus of analysis will be placed on the selection and structuring of school contents and on the didactic practices determined by the Ratio, 
seeking to connect them to the social groups that attended Jesuit colleges. ${ }^{1}$

The founders of the Society of Jesus, Ignatius of Loyola and his companions, did not intend to create a religious congregation committed to school education, as their initial motivation was directed to missionary activities in the Asian World, following the European Eastern expansion (Lacouture 1993). The concern with schools emerged from the intra-institutional need to provide "substantial" and regular education to Jesuit seminarians. However, when pressed by the growth of protestant religions and the religious wars, the Society of Jesus started to admit external students in their colleges, transforming them into catholic trenches, mainly after the Council of Trent. The Jesuits were established as the main modern Catholic Church militia, standing out as an active congregation, concerned with individualizing spirituality and characterized by a fighting language (Varela 1983).

In the 1540s, Jesuit colleges started to pop up around Europe, changing school education into one of the main pastoral actions of the Ignatian Congregation. The first educational institution that effectively admitted external students was the Messina College, in 1548, a practice which was extended, very rapidly, to other European, Asian, and American cities (Schmitz 1994). In Rome, the headquarters of the Society of Jesus was founded in 1551, the Roman College, becoming the school institution model for the Jesuits, the one which agglutinated their main theologians and pedagogues, and which tested the school practices that would be the basis for the Ratio Studiorum. In the following year, the German School was instituted, aiming at the formation of Jesuit staff from German regions, that were frontally hit by the whirlwind of Lutheran and Calvinist reforms (Meneses 1988).

The Ratio Studiorum was a pedagogic reinvention produced from the Catholic re-reading of Renaissance pedagogic writings and educational practices, as well as from the creation of a system of practices from the Jesuit colleges themselves. The first generation of teachers of the Society of Jesus was very much influenced by the pedagogic formulations of Erasmus and Vives, both concerning the teaching of classical Latin language and active school practices. On one hand, the modus parisiensis was chosen as an educational model for the first Jesuit colleges, not only because Ignatius of Loyola and his co-founding companions had studied at the Univer-

\footnotetext{
${ }^{1}$ Foucaultian inspired socio-historical reflections on the Jesuit "school machinery" are based on Varela and Alvarez-Uría (1991). On the concept of "monument-document", refer to Foucault (1995) and Le Goff (1995).
}

sity of Paris, but above all due to their teaching method, which was distinguished by teaching solid grammar, by grading classes and courses, by implementing exercises in the classes and by the individualization of the student (Durkheim 1995).

The "Constitutions of the Society of Jesus" dedicated the fourth part, entitled "The Learning and Other Means of Helping Their Neighbor That Are to Be Imparted to Those Who Are Retained in the Society", to the education of the new born Jesuit colleges. It is the legal-pedagogical milestone for the Society of Jesus, in which Ignatius of Loyola established the fundamental guidelines for the Jesuitic educational practice, indicating the need to produce the Ratio Studiorum (Loyola 1975). Furthermore, the 1599 Ratio is, above all, a product of the reflection systematization educational practices implemented in Jesuit colleges for half a century. The first Course of Studies was written by the rectors of the Messina College: De studiis Societatis Iesu, by Jerónimo de Nadal, and De Ratione Studiorum, by Hannibal du Coudret. From their experiences and observation at a number of colleges, but especially at the Roman College, where he worked as a teacher and prefect of studies, Diego de Ledesma published De ratione et ordine Collegii Romani, which should serve as a model for all the Society of Jesus' colleges, and it is considered the main individual contribution to the 1599 Ratio (Franca 1952).

From those partial beginnings, Father Claudio Acquaviva, fifth Superior General of the Society of Jesus, led the process to make a "definite" Ratio Studiorum. In 1586, he nominated a commission with six representatives to write a draft project, which was sent to the Jesuit provinces. After the provincial reviews, five years later, a new text was produced, sent to all the Jesuit colleges. After the approval of the reviewers nominated by the Superior General, in 1599, the Ratio atque Institutio Studiorum Societatis Jesu was officially approved by the Society of Jesus, becoming then mandatory in Jesuit colleges. In fact, the "definite" version of the Ratio responded to the need for the standardization of educational practices in the chain of Jesuit colleges, which was meteorically formed in the second half of the $16^{\text {th }}$ century. The first controlling pedagogical strategy adopted by the Society of Jesus was the establishment of "general officers", who would regularly visit and inspect the Jesuit colleges. Nevertheless, the diversity of visitors and the long intervals between visits did not contribute to develop the pedagogical standard, which would be established by the 1599 Ratio (Franca 1952). ${ }^{2}$

\footnotetext{
${ }^{2}$ The present essay is supported by the Portuguese translation by Father Leonel Franca in 1943 and published nine years afterwards; cf. Organização e Plano de Estudos da Companhia de Jesus, translated by Leonel
} 
The 1599 Ratio is an educational code comprising 467 rules, gathered in 30 sets, directed to the college agents and institutions of Jesuit colleges. The rules cover the administration, the course of studies, the school method and discipline, and were directed to the three classes of Jesuit teaching - lower classes, philosophy and theology - which had common pedagogical principles, but while these aimed at the formation of a Jesuit clergy and of other religious congregations, the lower classes would admit external students, who would follow other studies, mainly law and medicine. Approximately a third of those rules would guide the school content and practices of the lower classes, which were divided in "series": rhetoric, humanities, and grammar, being this last one subdivided in lower, middle and upper grammar. The Ratio determined that the five series should not mix through fusions or divisions and that the promotions from one series to the next should be conducted annually, but in the grammar classes this should happen only when the student could demonstrate mastering of the established knowledge. Those school degrees of intellectual perfection were inspired in the progressive and linear processes of search for spiritual perfection, ${ }^{3}$ prescribed in the "Spiritual Exercises".

\section{GIVING ANOTHER MEANING TO CLASSICAL KNOWLWDGE}

The central objective of the lower classes was to provide the Jesuit student with a solid grammatical knowledge, as some help and support for philosophy and mainly theology studies. The central nucleus of the curriculum of lower classes established by the Ratio was the teaching of classical languages and literatures, which were taught to all classes in a growing degree of complexity and perfection. The choice of literary school knowledge to be followed by all the Jesuit teachers was explicitly defined in the rule connected to the prelection: "In the prelections, only the ancient classics, never the modern writers, are to be explained." However, it meant to teach the Latin and Greek grammar in a formal way,

Franca (1952). Translated from Ratio atque Institutio Studiorum Societatis Iesu. Superiorum permissu, Neapoli, in Collegio eiusdem Societatis. Ex typographia Tarquinii Longui, MDXCVIII, 208 p., at the end, Neapoli, apud Tarquinium Longum, 1599.

${ }^{3}$ Just as it happens with the spiritual life, the school life had a progression towards perfection, because in the lower classes, the rhetoric, the last one, aimed at the "perfect education in eloquence", the upper classes of grammar had the objective of reaching "perfect knowledge of grammar", whereas the middle grammar classes aimed at "the knowledge, although still imperfect of all the grammar" [our emphasis] cf. Franca $(1952,192,204,208)$ and Loyola (1977). in a reduced context of the pagan mental frame of the Ancient times from which they came. "It was in this way that antiquity in the hands of the Jesuits could become an instrument for Christian education; they would not have been able to use the literature of their own age in the same way, imbued as it was with the spirit of rebellion against the Church" (Durkheim 1995, 235).

There was some concern in purging the ancient authors and isolating students from "impure writings" and the "evil and useless books". From this point of view, the Rule 34 of the Provincial, entitled "Prohibition of inconvenient books", said that the selection of books should be made in view of producing amenable and catholic students:

Be really careful, and consider this point as one of great importance, that under no circumstances our people should use, in classes, books by poets or others, which may be harmful to honesty and proper practice, unless they are purged from inconvenient facts and words, and if they cannot be purged, like Terence, it is preferable that they do not read them so that the nature of the content is not to offend the purity of the soul [our emphasis] (Franca 1952, 130).

Besides the work of "de-paganization" of GrecoRoman works, the Jesuits produced their own didactic writings, imbued with the Catholic-Tridentine mentality, such as the "Grammar by Father Emmanuel Alvarez", recommended for grammar classes.

However, among the classical languages and literatures, Latin and prose were predominant over Greek and poetry. The ideal to be followed in the "stages of progress" was the oral and written mastering of classical Latin, from some Roman writers. And among them there was a preference for Cicero, who should be learned and imitated in a progressive way in ascending ways of the lower classes. Indicating what should be common to all the lower classes, the Ratio says: "Above all, what is to be common is the reading of Cicero, so that the easiest things are to be asked to the least advanced group, the most difficult ones to the other groups" (Franca 1952, 168). Just as it was preferred for the prelection, Cicero was the main author, which should be imitated in compositions and evaluations of exams, tests, and disputes.

In the rhetoric class, the last one, it was required the exclusive use of Latin, but in the humanities and mainly in those of grammar, the use of vernacular language would be allowed, but as an instrument for the learning of Latin. The mandatory teaching of Latin is clearly expressed in the "Rules of the Teacher of the Lowest Grammar Class", which says: 
Especially the strict habit of speaking Latin should be observed except in the classes in which the disciples ignore it; so that in everything which refers to classes the mother language is never allowed to be used, and the ones who are negligent about this point shall receive a negative score; for that reason, the teacher shall always speak Latin (Franca 1952, 184).

The Latin language was also mandatory in theater presentations, as well as in college ceremonies. The hierarchy of school contents could be noticed as well in the awards given to students: in the rhetoric class, there were awards for Latin and Greek prose and poetry; in the humanities class, the Greek poems would be omitted, and in the grammar classes the ones with Greek and Latin poetry would be omitted. The number of awards to be distributed could vary according to the number of students, but the most important reward would be the one for Latin prose.

In the political and cultural structures of the Old Regime, Latin had a useful character, because it was the official language of the Catholic Church and of the absolutist States. But above all, it had the function of social distinction, for it was cultivated by court and bourgeois elites with the objective of keeping a distance from the old warrior nobility as well as from the popular classes (Elias 1993). Analyzing the Renaissance pedagogies, Durkheim states that Erasmus and Rabelais, in spite of diverging, both believed that the aristocratic education should encompass the esthetic preoccupation, not connected to practical life (Durkheim 1995). In the lower classes, whose crowning was the Latin rhetoric, a few students who undertook higher studies on theology, law or medicine effectively learned the Latin language.

The mandatory teaching of Greek language in the lower classes was not very well accepted by Spanish Jesuit colleges. The teaching of Greek was included by the 1586 commission and, despite some resistance, it was kept in the "definite" version of the Ratio. The introduction of Hebrew aimed at preparing the student for the reading of the Old Testament, conducted in the higher theological studies. On the other hand, the Ratio used to determine that in all the lower classes the Christian Doctrine would be taught twice a week and the spiritual readings would be encouraged, especially about the life of the Saints. In the lower classes, the Catholic-Tridentine doctrine was made of theological rudiments, which would be studied in detail and depth in the theology classes.

\section{MODERN BODY DISCIPLINE}

However, in the manufacture of Jesuit students of the lower classes, the transmission of expurgated literary content at the light of Tridentine Catholicism was combined with the teaching of "proper practices". In defining the aim of Jesuit education, the Ratio Studiorum would determine to its priests-teachers: "Concentrate especially on your intention, both in the classes and in offering the timeliness outside them, in molding the plastic soul of youth in the service and love of God, as well as in the virtues with which we should please Him" [our emphasis] (Franca 1952, 181).

The molding of the Jesuit student's soul predicted a set of disciplinary strategies and tactics to be put into practice inside and outside the classroom. This "school machinery" implied the control of time and space, a strict hierarchy, emulation and competition among students, individualization of school careers and encouragement of permanent activity of students. The Ratio guided teachers to always exercise students, making them active agents of the learning process. Durkheim considers this transformation as "a great revolution" which distinguished the modern educational practices from the medieval ones (Durkheim 1995). The Jesuit prescription of school exercise comes from the Ignatian ascetics, which predicted a set of progressive and linear spiritual exercises to obtain conversion and salvation. The permanent encouragement to exercise should create a complete net of stimulus that would not allow the students' passivity; instead, it would foster permanent school production. Referring to the class exercises, the pedagogical method of Jesuits is categorical: "Nothing slackens youthful diligence more than monotony." And so it prescribes that, as well as reading Cicero, the exercises and challenges should be common practices to the lower classes, according to an "active pedagogy".

The permanent action of Jesuit students in classes should be reached through the prescription of varied exercises, especially in written works, transforming the class in a "room for exercises". When analyzing the ruptures promoted by the reforming pedagogies of the $16^{\text {th }}$ century, among which there is the one from Jesuits, Petitat states: "An important change when comparing to the medieval pedagogy reinforces this schooling: the oral exercises are replaced by written works. The homework, tests and a number of exercises are written" (Petitat 1994,81 ). The Ratio would guide the teachers of lower classes to do writing work everyday, with the exception of Saturday, the day of disputations. It insisted on the individual correction of exercises, prescribing:

The written work of each pupil ought to be corrected daily by the teacher, since this leads to the very best results. If, however, there are too many pupils for this to be practicable, he should correct as many as possible so that those 
whom he passes over one day will be called on the next (Franca, 1952, 184-5).

The several exercises were stimulated by the prelection which had the objective of "introducing the student to a perfect understanding of the author", as explained by Leonel Franca:

The prelection, in its aim, is less informative than formative; its aim is not to communicate facts, but to develop and activate the spirit. (...) In the silence of his study bench [the student] will repeat afterwards the vital processes covered by the author and analyzed in the prelection (Franca 1952, 57-8).

The Ratio would give the detail of the steps for prelection to all teachers of the lower classes: the reading of a text, synthetic analysis of the text, detailed reading of each period and, finally, a presentation of the observations adapted to each class. If the teacher would find it convenient, some observations could be dictated, but never in excess, and the students should take notes only when they were told to. The dictations, common at medieval universities, were really minimized both by the pedagogical guidelines of Ignatius of Loyola and by the Ratio, which mirrored the modus parisiensis. The Jesuit colleges used several printed books, supplied by the new written press, and they took a special care for the school libraries.

Aiming at the encouragement of a "permanent state of alertness", the Ratio predicted the emulation and competition among students, groups and classes, recommending that teachers should conduct "class challenges", which should be well prepared and conducted with modesty and serenity. In the "Rules of the Teacher of the Lower Classes", the pedagogical method of the Society of Jesus stated:

The challenge, which can be organized either by questions from the teacher and correction from the rivals or by questions from the rivals to each other, should be valued and put into practice whenever time allows, to feed a decent emulation, which is a great stimulus to studies. The competition could be one against the other, or group against group, mainly the official ones, or it could provoke several of them; usually one will provoke another one in particular, one official another official; one particular rival may sometimes challenge an official, and if this one wins, he will get that graduation, or another prize or victory symbol (...). [our emphasis.] (Franca 1952, 187).

However, a challenge with the immediate class was also predicted, so that the students would live on the verge of a fight.
In the Ratio, the emulation was connected to the individualized system of control, evaluation, classification and awarding of students, which presupposed a strict school hierarchy. It was not by chance that the rules of the Ratio are shown in descending order: first by the provincial priest, followed by college authorities: the principal, the prefect of studies and the teachers: on the other hand, the students did not have any set of rules. In the Ratio prescriptions, one can notice the distance between the college directors and the students and the obedience imposed, characteristic of "totalitarian institutions". Among the college directors, the teachers should be subordinate to the principal, for discipline matters, and to the prefect of studies, both concerning the teaching and the discipline; the prefect of studies had to obey the principal. The classes were divided in two groups, so that each group would have its soldiers and officials, as if they were two army battalions. The Ratio says clearly: "To feed the emulation, as a rule the class may be divided in two fields, each one of them with their officials, one opposite the other, and each student is to have his rival. The first officials of both fields occupy a place of honor" (Franca 1952, 189).

The officials should be chosen every two months, according to a written prose test, which would classify the posts of honor. In each class, the teacher should nominate a censor or praetor, whose function was to control the frequency and the exercises in class, as well as the behavior of colleagues in the patio. The teacher had to take care of the progress of each one of the students. Concerning the control on frequency, the Ratio prescribed to teachers: "If someone is absent, send to their home a co-disciple or any other person and, if he cannot show acceptable excuses, he will be punished for his absence" (Franca 1952, 190-1).

In his school routine, the student would be examined by the prefect of studies and by the teacher: to get in he should take the admission exams, and in all classes he should take written tests - procedures were very well explained in the Ratio - and an oral exam. In the beginning of each year, the teacher should produce a standard for the students, classifying six categories, represented by the numbers from one to six. This process of panoptic vigilance made the Jesuit students lose the autonomy that university students had in the Middle Ages. With the "Spiritual Armies", the teacher should be the "learning director", who detained the correct and true knowledge, and he should be guided by paternal affection and have the mission of guiding the "exercising student".

The individualization and the constant government implied the control of time and space of students. The Ratio prescribed a uniform division of school time and 
space, indicating that the rhetoric classes should have two hours of class in the morning and the same time in the afternoon, and the humanities and grammar classes, two hours and a half both in the morning and in the afternoon period. In the specific rules for teachers in each class, the time division occupied a significant space, indicating in detail the activities to be developed in the four or five daily hours of class, including the Saturdays and holidays. There was concern about the detailed distribution of school time, the variety of activities and exercises, the moderation in hours of study, the introduction of small productive pauses. The proctor, who should always have with him a clock, and being his function to tell the teacher or the prefect of studies when it was time to start and finish school activities, strictly controlled the chronological time. Therefore, as well as with the manufactures and the protestant schools, the appropriation of students' time was introduced in Jesuit colleges of the $16^{\text {th }}$ century and established in their pedagogical method.

The Jesuit college had a convent organization, which was disseminated in the educational institutions of the $16^{\text {th }}$ century, and where the students were segregated from the danger and the pleasures of the world. The Ratio formulated strategies to discipline and pacify the school environment, seeking to watch students. In the classroom, each one should have their place defined by the prefect of studies or by the teacher: the noble ones would have a distinct place, and the Jesuit students and those from other congregations would be separate from the external students. To this end, it was determined to students: "In the classroom one should not go from one place to the next; instead, each one should stay in his place, humble and silent, paying attention to himself and his works. Do not leave the room without the teacher's permission" (Franca 1952, 221). Under the title "order in the patios", it prescribed: "In the patios and in the classrooms, even the high ones, no guns are tolerated, nor idleness, running and shouting, neither are allowed swearing, aggressiveness with words or facts; or whatever dishonest or frivolous act" (Franca 1952, 175). The students were also forbidden to take part in public shows, comedies and in the execution of condemned prisoners and of representing roles in theaters outside the college.

As an integral part of the fostering, the Ratio would predict a system of school awards, described in the "Norms for distribution of awards". There were annual public awards, specific for the five classes and given according to written and private tests, which were evaluated by a panel of three teachers, and a special award for those who had the best performance in Christian doctrine. Besides the tie-breaking criterion of tests, the norms indicated the procedures of the award distribution session, which should be public and solemn. For a larger visibility of the best ones, the names of those that were closer to the winners should also be read and awarded with some distinction. On the other hand, the Ratio determined that teachers would stimulate their students, in the classrooms, through small private awards or "victory symbols", given to those who won the adversary or who had performed any special effort.

Therefore, the pedagogical method of Jesuits proposed forming their students much more through fostering the school production than through imposing physical punishment, still very much used in the beginning of the Modern Age. The pedagogical tradition of appealing to physical punishment as a last resort, when the "good words and exhortations" would be finished, was founded by Ignatius of Loyola. Among other demonstrations, in 1552, he wrote a letter to Everard Mercurian, saying categorically: "It is not convenient that teachers of the Society punish except with words". The physical punishment predicted should be applied by the corrector, someone who did not belong to the Society of Jesus, so that no Jesuit teacher would touch or harm the body of students. Franca explains the corporal punishment process: "The blows should never be more than six; they should never hit the face or the head. Neither should the punishment be applied in a solitary place, but always in the presence of, at least, two witnesses" (Franca 1952, 62-63). Ultimately, after the verbal warnings and of the physical punishments, the elimination of the uncorrectable from the college was predicted, and they could, nevertheless, be re-admitted if the principal decided to agree. The substitution of physical punishment for a loving vigilance and a sweet domestication, more efficient and productive, proposed by the Ratio, was a trend which emerged in the $16^{\text {th }}$ century.

The "proper practices" were also produced among students through the encouragement of acts of pity, especially those of sacramental character. The Ratio would prescribe prayers before every class, which should be made with uncovered head and on one's knees, evening consciousness exam, daily saying of the rosary or praying for Virgin Mary, daily mass, monthly confession. The control of the frequency to the confession should be made through cards containing the name, surname and class of the student, which should be handled to confessors. The most pious students were encouraged to be part of the Marian Congregations, which had especial exercises for the devotion of the Virgin Mary, and they should be a support for the student population. With the objective of moralizing and Christianizing stu- 
dents, the Ratio predicted the organization of theatre plays, however they should be rare, in Latin language and with exclusively male characters.

\section{FINAL CONSIDERATIONS}

The Ratio Studiorum is a "monument-document" which is part of the emergence of a "new model of individual management" or of the "art of governing" in the beginning of the Western Modernity. According to Foucault, in the $16^{\text {th }}$ century there was a general problematization of the art of governing in several aspects of social life: the government of the States by princes, the government of the souls by the protestant and catholic reforms, the government of children by pedagogy, the government of oneself (Foucault 1988). Both the several protestant churches and the Tridentine Catholic Church produced new theological power-knowledge, for the salvation of souls, and a pedagogical one for the "perfect" formation of students. In the context of religious wars of the $16^{\text {th }}$ century, all Christian churches invested their reformed power-knowledge to mold, form, and manufacture the childhood and youth soul. To this end, the Jesuit pedagogue Juan Bonifacio concluded: "Childhood education is the renovation of the world". Durkheim diagnosed precisely the Society of Jesus' modernity when he concluded: "They (Jesuits) understood early that in order to get to their objective, it was not enough to preach, to confess, to catechize, and that the education of the youth was the true instrument in the control of souls" (Durkheim 1995, 219).

In the $16^{\text {th }}$ century, together with the establishment of absolutist States and noble courts, and the implementation of religious reforms in a context of religious wars, differentiated educational programs were formulated, which produced and naturalized social inequalities. First of all, princes and knights, according to the new ethos of the noble court, should be educated in the arms, as in the Middle Ages, but mainly in literature and morality. On the other hand, for the popular classes, who should be prepared to work with handcraft, the transmission of basic content was predicted, as well as the instilling of submission and obedience. However, there was an intermediary class, the ascending bourgeoisie, whose members would occupy important bureaucratic positions in the developing absolutist States, which should be educated in Latin literature and in the Christian virtues. Broadly speaking, the Jesuit colleges manufactured the "modern workers", coming from bourgeois strata, as well as the children of provincial aristocracy. Nevertheless, the Ratio aimed at manufacturing learned and male Catholic subjects, following the re-definition and the naturalization of the roles and of the education of the sexes, formulated by humanists and ecclesiasts, where men would have public roles - and for that purpose, they should receive more theoretical and refined studies - whereas the women would keep to the private space and be given a more practical and serious education (Varela 1997).

Until the suppression of the Society of Jesus by the Catholic Church, in 1773, the Ratio of 1599 ruled as a pedagogical method of the Jesuits, suffering small changes, improvements and addition of footnotes. After the French Revolution, with the "rehabilitation" of the Society of Jesus, the Ratio Studiorum was reconsidered to be adapted to a new situation created by the "double revolution", marked by industrial capitalism and by the national systems of education. Seen from the point of view of "a sign of the times", the Jesuits articulated a process of re-inventing the Ratio, whose reformed version was published in 1832 . In the $19^{\text {th }}$ century, the Ratio Studiorum lost the universality it had in the Old Regime, because, in spite of being still the official method of the Society of Jesus, it should be adapted to the political-cultural reality of each Jesuit province.

Concerning the curricular content, there was a discontinuity, because the classical literature was not the main line of thinking of the curriculum anymore, and it gave significant room to national languages and cultures, as well as to experimental sciences and mathematics. However, with some changes, the teaching method and the disciplinary mechanisms were kept and improved, seeking to form scholarly and catholic male subjects. The Society of Jesus created the boarding school for external students, as well as other religious congregations, such as the Marians and the Salesians, a true disciplinary institution that was disseminated in the "restoration" of Europe, and it was ruled by the "school machinery" formulated in the Ratio Studiorum. As an integral part of the "re-Europeanization" of Brazil, the boarding schools were established in Brazilian territory from mid- $19^{\text {th }}$ century on, and had a significant growth during the First Republic, when they were established in almost all the capitals of the Brazilian States, with the aim of educating great part of their bourgeois elite.

\section{REFERENCES}

Durkheim, Emile. 1995. A evolução pedagógica. Porto Alegre: Artes Médicas.

Elias, Norbert. 1993. El proceso de la civilización: investigaciones socio-genéticas y psicogenéticas, Madrid: Fondo de Cultura Económica. 
Foucault, Michel. 1988. "A governamentalidade". In Microfísica do poder, edited by Michel Foucault, 277293. Rio de Janeiro: Graal.

Foucault, Michel. 1995. A arqueologia do saber. Rio de Janeiro: Forense Universitária.

Franca, Leonel. 1952. O método pedagógico dos Jesuítas: o "Ratio Studiorum" - introdução e tradução, Rio de Janeiro: Agir.

Lacouture, Jean. 1993. Os Jesuitas - 1. A conquista. Lisboa: Estampa.

Le Goff, Jacques. 1990. "Documento-monumento". In História e memória, edited by Jacques Le Goff, 535549. Campinas: UNICAMP.

Loyola, Inácio de. 1975. Constituições da Companhia de Jesus, translation and notes by Joaquim Mendes Abranches, S.J., Lisboa: s. n.

Loyola, San Ignacio de. 1977. Obras Completas: transcripción, introducción y notas de Ignacio Iparraguirr y Candido de Dalmares. Madrid: Biblioteca de Autores Cristianos.

Meneses, Ernesto. 1988. El código educativo de La Compañia de Jesús. México: Universidad Iberoamericana.

Petitat, André. 1994. Produção da escola/produção da sociedade: análise sócio-histórica de alguns momentos decisivos da evolução escolar no Ocidente. Porto Alegre: Artes Médicas.

Schmitz, Egidio F. 1994. Os jesuitas e a educação: a filosofia educacional da Companhia de Jesus, São Leopoldo: UNISINOS.

Varela, Julia. 1983. Modos de educación en la España de la Contrarreforma. Madrid: La Piqueta.

Varela, Julia. 1997. Nacimiento de La mujer burguesa: El cambiante desequilibrio de poder entre los sexos, Madrid: La Piqueta.

Varela, Julia and Alvarez-Uría, Fernando. 1991. Arqueologia de La escuela, Madrid: La Piqueta. 